\title{
Reglur um viðbrögð og úrræði vegna óæskilegrar hegðunar alpingismanna á vettvangi starfsins
}

\author{
Friðrik Árni Friðriksson Hirst, doktorsnemi, Lagadeild Háskóla Íslands \\ Kristín Benediktsdóttir, dósent, Lagadeild Háskóla Íslands
}

\begin{abstract}
Útdráttur
Í greininni er fjallað um hvaða reglur gilda um óæskilega hegðun alpingismanna á vettvangi Alpingis, á borð við einelti, kynferðislega og kynbundna áreitni og ofbeldi. Verður sjónum beint að ákvæðum siðareglna fyrir alpingismenn sem leggja áherslu á heilbrigt starfsumhverfi innan pings sem utan og leggja bann við einelti, kynferðislegri og kynbundinni áreitni sem og annarri vanvirðandi framkomu af hendi alpingismanna í garð annarra pingmanna, starfsmanna pingsins og gesta pess. Jafnframt verður tekin afstaða til pess hvort og pá hvernig ákvæði laga og reglna á sviði vinnuverndar sem ætlað er að sporna gegn slíkri háttsemi á vinnustöðum eigi við um Alpingi og alpingismenn og hvernig pessar reglur spila saman við fyrrnefndar siðareglur. Pá verður varpað ljósi á hvort og pá með hvaða hætti hegðun sem siðareglurnar leggja bann við samkvæmt framansögðu geti varðað alpingismenn refsiábyrgð og skaðabótaábyrgð. Meginniðurstöður greinarinnar eru pær að í siðareglum fyrir alpingismenn felist sambærilegar kröfur til alpingismanna að pessu leyti og gilda um starfsfólk Alpingis samkvæmt lögum og reglum á sviði vinnuverndar. Pá geta alpingismenn bakað sér refsiábyrgð samkvæmt hegningarlögum sem og skaðabótaábyrgð vegna háttsemi sem lagt er bann við í viðkomandi ákvæðum siðareglnanna, að uppfylltum skilyrðum slíkrar ábyrgðar. Pótt alpingismenn njóti vissrar friðhelgi samkvæmt stjórnarskránni er umfang hennar takmarkað auk pess sem Alpingi getur ávallt ákveðið að aflétta henni.
\end{abstract}

Efnisorđ: Alpingi; alpingismenn; vinnuvernd; stjórnarskrá.

\author{
Icelandic Review of Politics and Administration Vol. 17, Issue 2 (195-214) \\ (C) 2021 Contacts: Friðrik Árni Friðriksson Hirst, faf@hi.is and Kristín Benediktsdóttir, kristben@hi.is \\ Article first published online December14th 2021 on http://www.stjornmalogstjornsysla.is \\ Publisher: Institute of Public Administration and Politics, Gimli, Sæmundargötu 10, 102 Reykjavík, Iceland \\ Stjórnmál \& stjórnsýsla 2. tbl. 17. árg. 2021 (195-214) Fræđigreinar \\ 〔 2021 Tengiliđir: Friđrik Árni Friðriksson Hirst, faf@hi.is og Kristín Benediktsdóttir, kristben@hi.is \\ Vefbirting 14. desember 2021 - Birtist á vefnum http://www.stjornmalogstjornsysla.is \\ Útgefandi: Stofnun stjórnsýslufræđa og stjórnmála, Gimli, Sæmundargötu 10, 102 Reykjavík \\ DOI: https://doi.org/10.13177/irpa.a.2021.17.2.3 \\ This work is licensed under a Creative Commons Attribution 3.0 License.
}




\section{Rules on responses and remedies for undesirable behavior of members of Althingi in a work-related context}

\section{Abstract}

The article explores the rules that apply to inappropriate behavior of members of Althingi, such as harassment, sexual and gender-based harassment and violence. The article discusses the provisions of the Code of Ethics for members of Althingi, which emphasize a healthy working environment inside and outside Althingi and prohibit harassment, sexual and gender-based harassment as well as other disrespectful treatment by members of Althingi towards other members, staff and guests. Furthermore, the article analyses whether rules in the field of labour protection, which are intended to prevent such conduct in the workplace, apply to Althingi and to members of Althingi, and how they interact with the Code of Ethics. It also analyses to what extent members of Althingi can incur criminal and tort liability for conduct that is prohibited in the Code of Ethics. The main conclusions of the article are that the requirements imposed by the Code of Ethics on members of Althingi are akin to those that apply to the staff of Althingi according to rules in the field of labour protection. Members of Althingi can also incur criminal liability pursuant to the General Penal Code as well as tort liability for conduct that is prohibited by the relevant provisions of the Code of Ethics, provided that the conditions of such liability are met. Although members of Althingi enjoy a certain degree of immunity pursuant to the Constitution, its scope is limited and can always be revoked by Althingi.

Keywords: Althingi; members of Althingi; labour protection; constitution.

\section{Inngangur}

Á síðustu misserum hefur mikið verið fjallað um viðbrögð og möguleg úrræði vegna mála sem varða einelti, kynferðislega og kynbundna áreitni og ofbeldi á vinnustöðum. Í lögum og stjórnvaldsfyrirmælum má finna ýmsar reglur til verndar starfsfólki gegn slíkri óæskilegri hegðun. Í greininni verður fjallað um pær reglur sem gilda pegar alpingismenn sýna af sér hegðun af framangreindum toga á vettvangi Alpingis, par á meðal hvaða reglur og sjónarmið eiga við um refsiábyrgð og skaðabótaábyrgð af slíku tilefni.

Í upphafi verður samhengisins vegna fjallað stuttlega um stjórnskipulag Alpingis, p.m.t. hlutverk og heimildir forseta og forsætisnefndar, svo og réttindi og skyldur alpingismanna sem kjörinna fulltrúa. Dví næst verður sjónum beint að ákvæðum siðareglna fyrir alpingismenn sem leggja áherslu á heilbrigt starfsumhverfi innan pings sem utan og leggja bann við einelti, kynferðislegri og kynbundinni áreitni sem og annarri vanvirðandi framkomu af hendi alpingismanna í garð annarra pingmanna, starfsfólks pingsins og gesta pess. Gerð verður grein fyrir inntaki og lagagrundvelli siðareglnanna sem og málsmeðferð vegna brota gegn peim. Pá verður tekin afstaða til pess hvort og pá hvernig ákvæði fyrrgreindra lagabálka og reglna á sviði vinnuverndar eigi við um Alpingi og alpingismenn og hvernig pessar reglur spila saman við siðareglurnar. Verður sjónum 


\section{STJÓRNMÁL \& \\ STJÓRNSÝSLA}

par beint að lögum nr. 46/1980 um aðbúnað, hollustuhætti og öryggi á vinnustöðum, reglugerð nr. 1009/2015 um aðgerðir gegn einelti, kynferðislegri áreitni, kynbundinni áreitni og ofbeldi á vinnustöðum, sem sett er með heimild í fyrrnefndum lögum, og lög nr. 150/2020 um jafna stöðu og jafnan rétt kynjanna. Einnig verður vikið að lögum nr. 40/2020 um vernd uppljóstrara sem ætlað er að stuðla að pví að starfsmenn tilkynni vinnuveitanda um ámælisverða háttsemi á borð við pá sem áður var lýst. Að pessu frágengnu verður varpað ljósi á hvort og pá með hvaða hætti óæskileg hegðun sem fer gegn siðareglum fyrir alpingismenn geti varðað alpingismenn refsingu og skaðabótaábyrgð og hvort sérstaða alpingismanna í stjórnskipuninni geri pað að verkum að peir séu undanpegnir slíkri ábyrgð í meira mæli en almennir borgarar.

Fjallað verður um framangreind viðfangsefni með vísun til viðeigandi réttarheimilda og pær túlkaðar á grundvelli hefðbundinnar lögfræðilegrar aðferðafræði með hliðsjón af dómaframkvæmd og skrifum fræðimanna par sem peim er til að dreifa. Megintilgangur greinarinnar er að draga fram hvort og pá hvaða sérsjónarmið eiga við um alpingismenn hvað viðkemur ósæmilegri hegðun á vettvangi Alpingis af peim toga sem hér hefur verið lýst. Fram til pessa hefur lítið sem ekkert verið fjallað um stöðu alpingismanna að íslenskum rétti að pessu leyti auk pess sem lítið hefur reynt á álitaefni tengd fyrrnefndum reglum fyrir dómstólum hér á landi. Pó er um pýðingarmikið umfjöllunarefni að ræða enda er Alpingi meginstoð stjórnskipunarinnar eins og rakið verður nánar hér í framhaldinu. Ekki er ætlunin að gera pessum atriðum tæmandi skil heldur draga fram pau sem mestu skipta, einkum í peim tilgangi að vekja athygli á álitaefnum sem lúta að stöðu alpingismanna samkvæmt framansögðu.

\section{Stjórnskipulag Alpingis}

Alpingi er samkoma pjóðkjörinna fulltrúa sem fer með veigamesta pátt ríkisvaldsins skv. 2. gr. stjórnarskrár lýðveldisins Íslands nr. 33/1944. Auk pess að vera aðalhandhafi löggjafarvaldsins ræður Alpingi einnig miklu um meginstefnur í stjórnarframkvæmd og hefur mikil bein og óbein áhrif á stjórn landsins, m.a. sem miðstöð pólitískrar umræðu í landinu. Er Alpingi með öðrum orðum lýðræðislegur vettvangur fyrir pau mál sem par eru tekin fyrir hvort sem pau varða löggjafarstörf, fjárstjórnarvald, utanríkismál, pjóðfélagsmál, ályktanir um einstök mál og eftirlit pingsins (Björg Thorarensen 2015, 241 242; Pórhallur Vilhjálmsson 2019, 54). Alpingi er pannig valdamesta stofnun pjóðfélagsins og meginstoð stjórnskipunarinnar (Ólafur Jóhannesson 1978, 179). Reglur sem gilda um starfshætti Alpingis sækja stoð í pá meginreglu sem leiða má af ákvæðum stjórnarskrár um sjálfræði pess, sem m.a. felst í pví að Alpingi setur sér sjálft reglur um skipulag sitt og starfshætti og framfylgir reglum til að tryggja frið í störfum pess, og hafa pað að markmiði að pingið geti sinnt störfum sínum sem pjóðping. Taka reglurnar pví til Alpingis sem heildar en ekki til einstakra pingmanna (Dórhallur Vilhjálmsson 2019, 54, 55).

Reglur um starfshætti Alpingis nefnast pingsköp. Í 58. gr. stjórnarskrárinnar er mælt svo fyrir að pingsköp Alpingis skuli sett með lögum, sbr. lög nr. 55/1991 um pingsköp Alpingis (pingskapalög). Í pingskapalögum er nánar tiltekið fjallað um starfshætti Alpingis í víðum skilningi, par á meðal um pingsetningu og -skipun, yfirstjórn og stjórn- 
sýslu pingsins, pingnefndir, framsetningu pingmála, eftirlit pingsins með handhöfum framkvæmdarvalds, fundarsköp og umræður á pingfundum, svo og pingflokka og pingmenn, p.m.t. pagnarskyldu, skráningu fjárhagslegra hagsmuna og siðareglur. Pess ber að geta að pingskapalög eru jafnrétthá öðrum almennum lögum og er breytt með sama hætti. Pau hafa aftur á móti pað sérkenni að pingið getur ákveðið að víkja frá peim í einstökum tilfellum með 2/3 hluta greiddra atkvæða, sbr. 95. gr. laganna.

Hér á eftir verður vikið að stöðu og hlutverki forseta Alpingis og forsætisnefndar, pingflokka og skrifstofustjóra og starfsmönnum Alpingis í stjórnskipulagi Alpingis. Er slík umfjöllun nauðsynleg strax í upphafi, einkum til að lýsa stöðu alpingismanna innan Alpingis og hvernig staða peirra er ólík starfsmanna á vinnumarkaði almennt.

\subsection{Forseti Alpingis og forsætisnefnd}

Í 52. gr. stjórnarskrárinnar er mælt fyrir um að Alpingi kjósi sér forseta úr röðum alpingismanna sem stýrir störfum pess, sbr. 3. gr. pingskapalaga. Forseti gengst jafnframt fyrir kosningu sex varaforseta sem mynda ásamt honum forsætisnefnd, sbr. 3. mgr. 3. gr. og 1. mgr. 10. gr. laganna og sinna fundarstjórn í fjarveru forseta og hafa pá að öllu leyti sömu starfsskyldur og valdheimildir og forseti, sbr. 6. mgr. 8. gr. sömu laga (Pórhallur Vilhjálmsson 2019, 63). Pingflokki, sem ekki á fulltrúa í forsætisnefnd, er heimilt með sampykki nefndarinnar að tilnefna áheyrnarfulltrúa til setu á fundum hennar. Forsætisnefnd skipuleggur pinghaldið og gerir starfsáxtlun fyrir hvert ping, sbr. 2. mgr. 10. gr. pingskapalaga, auk pess sem hún gegnir veigamiklu hlutverki í sambandi við stjórnsýslu og rekstur pingsins.

Um störf forseta Alpingis er nánar fjallað í 8. gr. pingskapalaga. Hann stjórnar umræðum á pingfundi og sér um að allt fari fram með góðri reglu, auk pess að sjá til pess að störf pingsins séu í samræmi við ákvæði stjórnarskrárinnar, pingskapa og annarra laga. Alpingismönnum er enn fremur skylt skv. 73. gr. pingskapalaga að lúta valdi forseta 1 hvívetna að pví er varðar að gætt sé góðrar reglu.

Мeð lögum nr. 85/2012 var bætt við 8. gr. pingskapalaga tilvísun til siðareglna fyrir alpingismenn. Af greinargerð með frumvarpi sem varð að lögum nr. 85/2012 má ráða að gengið hafi verið út frá pví að forseta Alpingis beri að sjá til pess að framkoma pingmanna sé í samræmi við siðareglur á pingfundum og í störfum pingsins (140. löggj.p. 2011-2012, pskj. 1606 - 852. mál, 7; sjá einnig Pórhallur Vilhjálmsson 2019, 63). Forsætisnefnd hefur einnig pað hlutverk að fjalla um mál sem varða siðareglur fyrir alpingismenn, framkvæmd peirra og brot á peim, en um siðareglurnar verður nánar fjallað í 3 . kafla.

Forseti Alpingis ber ábyrgð á rekstri pingsins og hefur æðsta vald í stjórnsýslu pess, sbr. 9. gr. pingskapalaga. Með lögum nr. 80/2021 var bætt nýjum VII. kafla við pingskapalög sem fjallar um skrifstofu og stjórnsýslu Alpingis. Í 1. mgr. 91. gr. er tekið fram að með stjórnsýslu Alpingis sé átt við pá starfsemi sem fer fram á vegum pingsins og forseti hefur æðsta vald í, sbr. 9. gr., eða sem forsætisnefnd er ætlað að fjalla um samkvæmt lögunum. Til stjórnsýslu Alpingis teljist enn fremur starfsemi sem forseta Alpingis eða forsætisnefnd er falin samkvæmt fyrirmælum í öðrum lögum eða samkvæmt 
ályktun Alpingis. Undir stjórnsýslu Alpingis fellur á hinn bóginn ekki sú starfsemi sem fram fer af hálfu Alpingis sem samkomu pjóðkjörinna fulltrúa, og heldur ekki starfsemi umboðsmanns Alpingis, ríkisendurskoðanda og rannsóknarnefnda samkvæmt lögum nr. 68/2011 um rannsóknarnefndir, sbr. 2. mgr. 91. gr. pingskapalaga.

Samkvæmt framansögðu má segja að störf forseta Alpingis séu tvískipt, annars vegar störf sem snúa að pingstörfum eins og fundarstjórn og hins vegar stjórnsýslustörf. Hvílir sú skylda á forseta að beita valdi sínu til að tryggja að pingið starfi í samræmi við stjórnarskrá, pingskapalög og eftir atvikum önnur lög (Pórhallur Vilhjálmsson 2019, 62). Forseti Alpingis getur til að mynda gert hlé á eða slitið pingfundi ef óregla ríkir, sbr. 73. gr. pingskapalaga. Đá getur hann vítt alpingismann ef hann talar óvirðulega um forseta Íslands eða ber pingið, ráðherra eða einhvern pingmann brigslyrðum eða víkur með öllu frá umtalsefninu, og sé hann víttur tvisvar á sama pingfundi getur forseti svipt hann málfrelsi á peim fundi með sampykki fundarins, sbr. 98. gr. pingskaplaga (um nánari umfjöllun um pingvítur og heimild til pess að svipta pingmann málfrelsi vísast til Pórhallur Vilhjálmsson 2019, 73-80). Forseti hefur pó ekki boðvald yfir alpingismönnum í peim skilningi að hann getur ekki gefið alpingismönnum fyrirmæli um hvernig peir skulu rækja pingstörfin, t.d. greiða atkvæði um einstök mál. Hann getur heldur ekki, par sem framangreindum úrræðum sleppir, beitt einstaka alpingismenn viðurlögum pó peir virði ekki úrskurði hans til að framfylgja góðri reglu í pingstörfum (um nánari umfjöllun um hvað sé góð regla og um úrskurði og málsmeðferð forseta vísast til pórhallur Vilhjálmsson 2019, 67-72, 86-91).

\section{2 pingflokkar}

pingflokkar á Alpingi gegna margpættu hlutverki í tengslum við skipulagningu og framkvæmd pingstarfa, enda hefur verið litið á pingflokka sem hina pólitísku grunneiningu í starfi pingsins en ekki einstaka pingmenn. Hafa pingflokkar jafnframt verið taldir forsenda fyrir skilvirkni í störfum Alpingis (sjá Björg Thorarensen 2015, 254-256; Dorsteinn Magnússon 2011, 349-351; Stefanía Óskarsdóttir 2011, 234-235).

pótt ekki sé minnst á pingflokka í ákvæðum stjórnarskrárinnar er ákvæði um pá víða að finna í pingskapalögum. Í 1. mgr. 85. gr. pingskapalaga er t.d. ráðgert að formenn pingflokka komi fram fyrir peirra hönd gagnvart forseta Alpingis og öðrum pingflokkum og pingmönnum. Pá skal forseti hafa reglulega samráð við formenn pingflokka, eða fulltrúa peirra, um skipulag pingstarfa og leggja fyrir pá til umfjöllunar starfsáætlun pingsins og áætlanir um pingstörf hverrar viku, sbr. 1. mgr. 86. gr. laganna. Enn fremur hefur forseti samráð við formenn pingflokka um fyrirkomulag umræðna um mikilvæg mál, sbr. 2. mgr. 86. gr. laganna. pá hafa forseti og forsætisnefnd samráð við formenn pingflokka um pær reglur sem peim er falið að setja samkvæmt pingskapalögum, sbr. 3 . mgr. 86. gr. peirra.

\subsection{Skrifstofustjóri og annað starfsfólk Alpingis}

Forsætisnefnd ræður skrifstofustjóra Alpingis til sex ára í senn og ákveður laun hans og önnur starfskjör, en hann stjórnar skrifstofu Alpingis og framkvæmdum á vegum pings- 
ins, og hefur umsjón með fjárreiðum pess og eignum í umboði forseta, sbr. 1. mgr. 11. gr. pingskapalaga, eins og ákvæðinu var breytt með lögum nr. 80/2021. Með peim lögum var einnig bætt við nýrri 90. gr. pingskapalaga, par sem lýst er hlutverki og verkefnum skrifstofu Alpingis. Hlutverk hennar felst samkvæmt ákvæðinu í pví að styðja við starfsemi Alpingis svo að pingið, sem handhafi ríkisvalds, geti sinnt hlutverki sínu samkvæmt stjórnarskrá og lögum. Pá eru helstu verkefni hennar pau að vera forseta til aðstoðar og framfylgja ákvörðunum forseta og forsætisnefndar auk ákvarðana á fundi forseta með pingflokksformönnum, að veita alpingismönnum, nefndum og pingflokkum faglega aðstoð og pjónustu, að hafa á hendi almennan rekstur pingsins og stjórnsýslu, og að varðveita og miðla upplýsingum um hlutverk og starfsemi Alpingis.

Skrifstofustjóri Alpingis er embættismaður, sbr. 1. tölul. 1. mgr. 22. gr. laga nr. 70/1996 um réttindi og skyldur starfsmanna ríkisins. Forseti Alpingis setur skrifstofustjóra erindisbréf, sbr. lokamálslið 1. mgr. 11. gr. pingskapalaga. Síðastnefnt ákvæði er nýmæli sem bætt var við pingskapalögin með áðurnefndum lögum nr. 80/2021. Í athugasemdum með frumvarpi pví sem varð að fyrrnefndum lögum nr. 80/2021 var talið eðlilegt að skrifstofustjóra væri sett erindisbréf par sem kveðið væri skýrt á um starfssvið hans og starfsskyldur, sérstaklega par sem pær kunna að skarast við valdheimildir forseta Alpingis eða forsætisnefndar (151. löggj.p. 2020-2021, pskj. 1611 - 468. mál, 12).

Meðal hlutverka skrifstofustjóra er að sitja fundi forsætisnefndar og vera forseta Alpingis og nefndinni til aðstoðar í öllu er varðar stjórn pingsins, sbr. 2. mgr. 11. gr. pingskapalaga. Pá situr skrifstofustjóri, eða fulltrúi hans, pingfundi og er forsetum til aðstoðar, sbr. 1. mgr. 12. gr. laganna. Samkvæmt 3. mgr. 11. gr. pingskapalaga kemur í hlut skrifstofustjóra Alpingis að skipuleggja starfsemi skrifstofunnar og ráða annað starfsfólk Alpingis. Af fyrrnefndu ákvæði leiðir jafnframt að skrifstofustjóri er í fyrirsvari gagnvart starfsfólki pingsins pegar teknar eru ákvarðanir um réttindi og skyldur pess samkvæmt lögum og kjarasamningum. Pá er skrifstofustjóri i fyrirsvari gagnvart stéttarfélögum starfsfólks Alpingis við gerð kjarasamninga og pegar gerðir eru stofnanasamningar við slík stéttarfélög. Framangreind ákvæði um fyrirsvar skrifstofustjóra gagnvart starfsfólki Alpingis og stéttarfélögum peirra eru nýmæli sem bættust við með fyrrnefndum lögum nr. 80/2021 sem ætlað var að skýra verkaskiptingu forseta og skrifstofustjóra að pessu leyti (151. löggj.p. 2020-2021, pskj. 1611 - 468. mál, 12).

Annað starfsfólk Alpingis en skrifstofustjóri telst til starfsmanna ríkisins samkvæmt lögum nr. 70/1996 um réttindi og skyldur starfsmanna ríkisins. Dess má geta að með lögum nr. 80/2021 var ákveðið að skipta orðinu „starfsmenn“ í pingskapalögum út fyrir orðið „starfsfólk“ með vísan til pess að pað væri hlutlausara orð (151. löggj.p. 20202021, pskj. 1611 - 468. mál, 14). Var par ekki um efnislega breytingu að ræða enda ýmist vísað til starfsmanna eða starfsfólks í öðrum lagabálkum, til að mynda peim sem fjallað verður um í 4. kafla. Taka ber fram að alpingismenn teljast ekki til starfsfólks Alpingis í peim skilningi sem hér um ræðir enda njóta peir sérstöðu í stjórnskipuninni sem lýðræðislega kjörnir fulltrúar eins og rakið verður hér í framhaldinu, sbr. einnig 1. mgr. 2. gr. laga nr. 70/1996 sem undanpiggur alpingismenn gildissviði peirra laga. 


\section{STJÓRNMÁL \& \\ STJÓRNSÝSLA}

\section{Um réttindi og skyldur alpingismanna}

Alpingismenn eru pjóðkjörnir til fjögurra ára en kjörgengur við kosningar til Alpingis er hver sá ríkisborgari sem kosningarrétt á til peirra og hefur óflekkað mannorð, að frátöldum hæstaréttardómurum, sbr. 1. mgr. 31. gr. og 34. gr. stjórnarskrárinnar. Sérhver nýr alpingismaður skal vinna drengskaparheit að stjórnarskránni pegar kosning hans hefur verið tekin gild, sbr. 47. gr. hennar. Um réttindi, kjör og starfsskyldur alpingismanna fer nánar eftir ákvæðum stjórnarskrárinnar, sem eru að vísu fáorð um pessi atriði, og eftir ákvæðum pingskapalaga og laga nr. 88/1995 um pingfararkaup alpingismanna og pingfararkostnað (sjá Björg Thorarensen 2015, 302-306, 318-234).

Sem pjóðkjörnir umboðsmenn pjóðarheildarinnar hafa alpingismenn sérstöðu í stjórnskipuninni og er réttarstaða peirra mjög frábrugðin réttarstöðu starfsmanna ríkisins, bæði varðar upphaf og lok starfa og starfsskyldur. Deir lúta ekki boðvaldi yfirboðara um rækslu starfa sinna, heldur eru pað kjósendur, p.e. pjóðarheildin, sem peir fara með umboð fyrir eins og áđur greinir (sjá Björg Thorarensen 2015, 322). Peir njóta ríks frelsis um hvernig peir rækja pingstörfin en skv. 48. gr. stjórnarskrárinnar eru peir eingöngu bundnir við sannfæringu sína og eigi við neinar reglur frá kjósendum sínum. Eftir sem áður eru alpingismenn bundnir af peim almennu reglum pingskapalaga og annarra laga sem um störf peirra gilda, og má par t.d. nefna 4. mgr. 78. gr. pingskapalaga sem mælir fyrir um að enginn alpingismaður megi greiða atkvæði með fjárveitingu til sjálfs sín. Đá lúta alpingismenn jafnframt yfirstjórnarvaldi forseta Alpingis hvað viðkemur góðri reglu í pingstörfum, eins og fjallað var um í kafla 1.1.

Alpingismenn njóta skv. 1. mgr. 49. gr. stjórnarskrárinnar friðhelgi gegn pví að sæta gæsluvarðhaldi eða að sakamál sé höfðað gegn peim meðan Alpingi er að störfum. Фаð verður ekki gert nema með sampykki pingsins, en sampykki pingsins parf pó ekki ef alpingismaður er „staðinn að glæp“, eins og pað er orðað í stjórnarskrárákvæðinu. Enn fremur njóta pingmenn sérstaks málfrelsis skv. 2. mgr. 49. gr. stjórnarskrárinnar, par sem segir að enginn alpingismaður verði krafinn reikningsskapar utan pings fyrir pað sem hann hefur sagt í pinginu nema Alpingi leyfi. Að 49. gr. stjórnarskrárinnar verður aftur vikið í 5. og 6. kafla.

Í 50. gr. stjórnarskrárinnar er mælt fyrir um að glati alpingismaður kjörgengi missi hann rétt pann er pingkosningin hafði veitt honum, en sem fyrr segir er kjörgengur við pingkosningar hver sá ríkisborgari sem kosningarrétt á til peirra og hefur óflekkað mannorð, að frátöldum hæstaréttardómurum, sbr. 34. gr. stjórnarskrárinnar. Hugtakið óflekkað mannorð er skilgreint í 5. gr. laga nr. 24/2000 um kosningar til Alpingis, eins og ákvæðinu var breytt með 2. gr. laga nr. 141/2018 (verður 3. mgr. 6. gr. nýrra kosningalaga nr. 112/2021 sem taka gildi 1. janúar 2022 og leysa af hólmi lög nr. 24/2000). Segir par að enginn teljist hafa óflekkað mannorð sem hlotið hafi dóm fyrir refsivert brot og refsing sé óskilorðsbundið fangelsi, frá peim degi pegar dómur er upp kveðinn og par til afplánun er að fullu lokið. Framangreind atriði koma einnig til umfjöllunar í 5. kafla er lýtur að refsiábyrgð alpingismanna. 


\section{Siðareglur fyrir alpingismenn}

Siðareglur fyrir alpingismenn voru sampykktar af Alpingi 16. mars 2016 með pingsályktun nr. 23/145 (145. löggj.p. 2015-2016, pskj. 1031 - 115. mál) samkvæmt heimild í 1. mgr. 88. gr. pingskapalaga. Pingsályktanir hafa verið taldar til réttarheimilda í íslenskum rétti, pótt pær hafi vissulega ólíkan tilgang og réttlægri stöðu en almenn lög frá Alpingi (sjá Sigurður Líndal 2007, 115-116; Ármann Snævarr 1989, 171, en báðir höfundar flokka pingsályktanir undir settan rétt).

Siðareglurnar taka til alpingismanna og starfa peirra og fela í sér viðmið um hátterni peirra sem pjóðkjörinna fulltrúa og er tilgangur reglnanna að efla gagnsæi í störfum alpingismanna og ábyrgðarskyldu peirra, svo og tiltrú og traust almennings á Alpingi, sbr. 1. gr. reglnanna. Reglurnar gilda um alpingismenn við opinbera framgöngu peirra og snerta skyldur peirra sem pjóðkjörinna fulltrúa, sbr. 2. gr. reglnanna.

Með pingsályktun nr. 18/148 frá 5. júní 2018 (148. löggj.p. 2017-2018, pskj. 1100 _ 443. mál) var bætt við siðareglurnar ákvæðum par sem hnykkt er á pví að alpingismenn skuli leggja sig fram um að skapa í störfum sínum heilbrigt starfsumhverfi innan pings sem utan og hvarvetna par sem peir sinna störfum sínum, par sem hafnað er hvers konar kynferðislegri eða kynbundinni áreitni, einelti eða annarri vanvirðandi framkomu, sbr. nýjan d-lið 1. mgr. 5. gr. siðareglnanna. Pá skuli alpingismenn ekki sýna öðrum pingmönnum, starfsmönnum pingsins eða gestum kynferðislega eða kynbundna áreitni, leggja pá í einelti eða koma fram við pá á annan vanvirðandi hátt, sbr. nýja 8. gr. siðareglnanna.

Í greinargerð með tillögu til pingsályktunar nr. 18/148 er lýst pví markmiði fyrrnefndra breytinga á siðareglunum að pað komi fram með skýrum hætti að peim sé ætlað að stuðla að öruggu og heilbrigðu starfsumhverfi innan pings par sem hvers konar áreitni, kynferðislegri eða kynbundinni, og annarri vanvirðandi framkomu sé afdráttarlaust hafnað. Alpingi sé ekki hefðbundinn vinnustaður sem sætir stjórn tiltekins vinnuveitanda og pví eigi vinnuverndarlöggjöf ekki við um Alpingi með sama hætti og um hefðbundna vinnustaði. Pau markmið sem búa að baki jafnréttis- og vinnuverndarlöggjöf, um að gera fólki kleift að sinna starfi sínu án pess að eiga á hættu að purfa að pola kynferðislega áreitni og stuðla pannig að öruggu og heilbrigðu starfsumhverfi, eigi pó jafn vel við um alpingismenn, sem og starfsmenn og gesti pingsins, og aðra. Dví sé ,nauðsynlegt að skýrlega liggi fyrir hvernig eigi að fyrirbyggja og bregðast við kynferðislegri áreitni á Alpingi ekki síður en á venjulegum vinnustöðum“ (148. löggj.p. 2017-2018, pskj. 629 - 443. mál, 2; um séreðli pingstarfa samanborið við önnur störf, sjá einnig Erikson \& Josefsson 2020, 2, 5).

Í greinargerðinni er jafnframt gert ráð fyrir endurskoðun á reglum forsætisnefndar um meðferð erinda og málsmeðferð samkvæmt siðareglum fyrir alpingismenn vegna ætlaðra brota gegn peim og að samin verði sérstök viðbragðs- og aðgerðaáætlun í ljósi peirra nýmæla sem bætt var við siðareglurnar sem áður var getið (148. löggj.p. 20172018, pskj. 629 - 443. mál, 3). Slík viðbragðs- og aðgerðaáætlun hefur ekki litið dagsins ljós pegar petta er ritað. Á hinn bóginn hefur síðan 2013 verið í gildi aðgerðaáxtlun sem miðast við starfsfólk Alpingis og sett er í samræmi við reglugerð nr. 1009/2015 og jafn- 
réttisáætlun skrifstofu Alpingis. Er par átt við ráðna starfsmenn pingsins en ekki kjörna alpingismenn. Markmið peirrar aðgerðaáætlunar er að tryggja starfsfólki Alpingis heilbrigt og öruggt starfsumhverfi með samskiptasáttmála starfsfólks að leiðarljósi. Áætlunin nær yfir samskipti starfsfólks Alpingis og annarra sem pað á samskipti við í tengslum við starf sitt. Undir petta falla einnig athafnir og skipulagðir samfundir sem eiga sér stað utan vinnustaðarins, ef peir hafa áhrif á samskipti á vinnustað. Í aðgerðaáætluninni er pví slegið föstu að einelti, kynferðisleg og kynbundin áreitni og ofbeldi, í hvaða mæli eða mynd sem pað birtist, verði ekki látið viðgangast á vinnustaðnum. Đað sé á ábyrgð bæði stjórnenda og starfsfólks að fyrirbyggja og bregðast við slíkri hegðun (Áætlun um aðgerðir gegn einelti, kynferðislegri og kynbundinni áreitni og ofbeldi, 3. útgáfa, júní 2021; Jafnréttisáætlun skrifstofu Alpingis, 11. maí 2021).

Forsætisnefnd fjallar um mál er varða siðareglur fyrir alpingismenn, framkvæmd peirra og brot á peim, sbr. 2. mgr. 88. gr. pingskapalaga, sbr. einnig umfjöllun í kafla 1.1. og 17. og 18. gr. siðareglnanna. Í pví sambandi nýtur forsætisnefnd ráðgjafar siðanefndar priggja manna sem hafa sérpekkingu á störfum Alpingis, lögfræði og heimspeki eða hagnýtri siðfræði, sbr. 16. gr. siðareglnanna. Lætur siðarnefndin í té álit sitt á pví hvort pingmaður hafi með hátterni sínu brotið gegn hátternisskyldum sínum og meginreglum um hátterni, sbr. 5. gr. siðareglnanna. Forsætisnefnd getur falið nefndinni að fjalla um einstök mál, sbr. 4. gr. siðareglnanna. Er nefndin að öðru leyti forsætisnefnd og pingmönnum til ráðgjafar um framkvæmd siðareglnanna, sbr. 17. og 18. gr. peirra. Í núgildandi málsmeðferðarreglum sem settar voru á grundvelli siðareglnanna má finna nánari ákvæði um eftirlit forsætisnefndar með framkvæmd siðareglnanna og úrlausn einstakra mála vegna ætlaðra brota gegn peim (Reglur um meðferð erinda og málsmeðferð samkvæmt siðareglum fyrir alpingismenn, 29. ágúst 2016).

\section{Reglur um vinnuvernd og öryggi starfsmanna}

Eins og rakið var í kaflanum hér á undan kemur pað sjónarmið fram í greinargerð með tillögu til pingsályktunar nr. 18/148, sem breytti siðareglum fyrir alpingismenn, að par sem Alpingi sé ekki hefðbundinn vinnustaður sem sætir stjórn tiltekins vinnuveitanda eigi vinnuverndarlöggjöf ekki við um Alpingi með sama hætti og um hefðbundna vinnustaði. Í tilefni af pessu sjónarmiði verður pví velt upp í pessum kafla hvort og að hvaða marki alpingismenn og Alpingi sem „,vinnustaður“ falla undir eftirfarandi lög og reglugerð á sviði vinnuverndar:

- Lög nr. 46/1980 um aðbúnað, hollustuhætti og öryggi á vinnustöðum og reglugerð nr. 1009/2015 um aðgerðir gegn einelti, kynferðislegri áreitni, kynbundinni áreitni og ofbeldi á vinnustöðum, sem sett er með stoð í fyrrnefndum lögum.

- Lög nr. 150/2020 um jafna stöðu og jafnan rétt kynjanna.

- Lög nr. 40/2020 um vernd uppljóstrara.

Tveir fyrstnefndu lagabálkarnir auk reglugerðarinnar eiga pað sammerkt að pau leggja annars vegar tilteknar skyldur á vinnuveitendur (atvinnurekendur) um að gera ráðstafanir 
í págu öryggis starfsfólks síns, m.a. gagnvart einelti, ofbeldi og áreitni á vinnustaðnum, og hins vegar gera pau kröfur til atvinnurekenda, yfirmanna og annarra starfsmanna um að sýna ekki af sér slíka hegðun. Síðastnefndu lögunum, um vernd uppljóstrara, er ætlað að stuðla að pví að starfsmenn tilkynni vinnuveitanda um ólöglega eða ámælisverða háttsemi á vinnustað sem gerir vinnuveitanda kleift að bregðast við pví. Allir pessir prír lagabálkar og reglugerðin sem að framan er getið eru pví nátengd.

\subsection{Vinnuverndar- og jafnréttislöggjöf}

\subsubsection{Lög um aðbúnad, bollustubatti og öryggi á vinnustöðum o.fl.}

Lög nr. 46/1980 um aðbúnað, hollustuhætti og öryggi á vinnustöðum gilda um alla starfsemi par sem fleiri en einn vinna, hvort sem um er að ræða eigendur fyrirtækja eða starfsmenn, fyrir utan pegar um er að ræða loftferðir og áhafnir og siglingamál eða önnur mál sem falla undir Samgöngustofu, sbr. 2. gr. og 1. og 2. mgr. 3. gr. laganna. Reglugerð nr. 1009/2015 um aðgerðir gegn einelti, kynferðislegri áreitni, kynbundinni áreitni og ofbeldi á vinnustöðum er sett á grundvelli laga nr. 46/1980, sbr. e-lið 38. gr., og er gildissvið hennar pað sama og fyrrnefndra laga, sbr. 1. gr. reglugerðarinnar. Reglugerðin geymir skilgreiningar á peirri háttsemi sem henni er beint gegn samkvæmt framansögðu, sbr. 3 . gr., sem og ákvæði um áætlanagerð og verkferla til að fyrirbyggja og bregðast við hegðun af framangreindum toga. Vísast par einkum til II. kafla reglugerðarinnar er varðar skriflega áætlun um öryggi og heilbrigði á vinnustað, III. kafla um skyldur atvinnurekanda og IV. kafla um skyldur starfsmanna. Meðal annars er lögð skylda á starfsmenn í 9. gr. um að tilkynna atvinnurekanda o.fl. um háttsemi af framangreindu tagi á vinnustaðnum. Аð sama skapi skal atvinnurekandi skv. 7. gr. reglugerðarinnar bregðast við með ákveðnum hætti berist honum kvörtun eða vitneskja um slíka háttsemi á vinnustaðnum.

Samkvæmt 4. mgr. 12. gr. laga nr. 46/1980 telst atvinnurekandi í skilningi laganna sá sem hefur umsjón með starfsemi ef um opinberan rekstur er að ræða. Um pað álitaefni hvort Alpingi falli hér undir skal tekið fram að fyrrnefnd viðbragðs- og aðgerðaáætlun frá júní 2021, sem tekur til starfsfólks Alpingis, er sett á grundvelli laga nr. 46/1980 og reglugerðar nr. 1009/2015, sbr. umfjöllun í 3. kafla. Í pví felst staðfesting á pví að umrædd lög og reglugerð eru almennt talin taka til Alpingis sem vinnustaðar. Kemur pá til álita hver teljist „atvinnurekandi“ í skilningi nefndra laga og reglugerðar í tilfelli Alpingis. Nærtækara er að líta á forseta Alpingis sem atvinnurekanda fremur en skrifstofustjóra pingsins, par sem hinn fyrrnefndi ber ábyrgð á rekstri Alpingis og hefur æðsta vald í stjórnsýslu pess, sbr. 9. gr. pingskapalaga, en skrifstofustjóri stjórnar skrifstofu Alpingis í umboði forseta, sbr. 1. mgr. 11. gr. pingskapalaga, sbr. umfjöllun í köflum 1.1 og 1.3. Samkvæmt framansögðu kemur í hlut forseta Alpingis að tryggja starfsmönnum pingsins öruggt starfsumhverfi í samræmi við pær kröfur til aðbúnaðar og öryggis á vinnustöðum sem birtast í umræddum lögum og reglugerð.

Hafa má í huga að málsmeðferðarreglur pær sem birtast í reglugerð nr. 1009/2015 eru ekki einungis settar til verndar hagsmunum pess sem kvartar yfir broti heldur einnig pess sem sakaður er um brot. Til marks um рað er dómur Hastaréttar 23. september 2021 i máli nr. 15/2021, par sem uppsögn B ses. á starfsmanninum A vegna ætlaðrar kyn- 
ferðislegrar áreitni og ofbeldi gagnvart öðru starfsfólki B ses. innan vinnustaðar var talin ólögmæt með vísan til pess að B ses. hefði í grundvallaratriðum vikið frá ákvæðum reglugerðarinnar við meðferð máls A. Var petta metið B ses. til sakar og var B ses. pví gert að greiða A miskabætur, en kröfu A um bætur fyrir ætlað fjártjón var hafnað vegna sönnunarskorts.

Samkvæmt 24. gr. laga nr. 46/1980 er starfsmaður í framangreindum skilningi hver sá sem vinnur launuð störf 1 annarra pjónustu. Er pá fyrir hendi starfssamband milli atvinnurekandans og starfsmannsins, par sem starfsmaðurinn vinnur í págu pess fyrrnefnda gegn greiðslu samkvæmt ráðningarsamningi og lýtur boðvaldi hans. Pótt alpingismenn piggi laun úr ríkissjóði er réttarstaða peirra mjög frábrugðin réttarstöðu starfsmanna ríkisins, bæði hvað varðar upphaf og lok starfa og starfsskyldur. Peir lúta ekki boðvaldi yfirboðara um rækslu starfa sinna, heldur eru pað kjósendur, p.e. pjóðarheildin, sem peir fara með umboð fyrir eins og áður greinir (sjá Björg Thorarensen 2015, 322). Af pessu leiðir að alpingismenn verða ekki taldir til starfsmanna í skilningi laga nr. 46/1980 og reglugerðar nr. 1009/2015. Aftur á móti gegnir öðru máli um starfsfólk Alpingis par sem pað fellur eins og áður segir undir fyrrnefndar reglur.

\subsubsection{Jafnréttislög}

Í 1. gr. laga nr. 150/2020 um jafna stöðu og jafnan rétt kynjanna (jafnréttislaga) kemur fram að markmiðið með lögunum sé að koma í veg fyrir mismunun á grundvelli kyns og koma á og viðhalda jafnrétti og jöfnum tækifærum kynjanna á öllum sviðum samfélagsins. Tekið er fram að allt fólk skuli eiga jafna möguleika á að njóta eigin atorku og proska hæfileika sína óháð kyni. Með kyni î lögunum sé átt við konur, karla og fólk með hlutlausa skráningu kyns í pjóðskrá nema annars sé sérstaklega getið. Talið er upp í 13 stafliðum hvernig pessu markmiði skuli m.a. náð en par á meðal er að vinna gegn kynbundnu ofbeldi, kynbundinni áreitni og kynferðislegri áreitni, sbr. i-lið 1. gr. en í 4.-6. tölul. 2. gr. jafnréttislaga eru pessi prjú hugtök skilgreind.

Rétt er að vekja athygli á pví að skilgreiningar í 2. gr. jafnréttislaga á hugtökunum kynbundin áreitni og kynferðisleg áreitni eru víðtækari en í reglugerð nr. 1009/2015. Pannig ræðir reglugerðin um að slík háttsemi purfi að vera „1́ ópökk“ pess sem verður fyrir henni, en tilvitnuð orð koma ekki fyrir í sambærilegum skilgreiningum jafnréttislaga. Í greinargerð með frumvarpi til jafnréttislaga kemur fram að pað hafi pótt óparft að taka pað fram að háttsemin pyrfti að vera „, ópökk“ viðkomandi, enda hefði kynbundin áreitni pann tilgang eða pau áhrif að misbjóða virðingu viðkomandi og skapa aðstæður sem eru ógnandi, fjandsamlegar, niðurlægjandi, auðmýkjandi eða móðgandi fyrir viðkomandi. Pá hefði kynferðisleg áreitni pann tilgang eða pau áhrif að misbjóða virðingu pess sem fyrir henni verður, einkum pegar hegðunin leiðir til ógnandi, fjandsamlegra, niðurlægjandi, auðmýkjandi eða móðgandi aðstæðna (151. löggj.p. 2020-2021, pskj. 14 - 14. mál, 26; sjá til samanburðar lög nr. 86/2018 um jafna meðferð á vinnumarkaði par sem hugtakið áreitni er skv. 2. gr. miðað við háttsemi sem er „í ópökk“ viðkomandi ólíkt skilgreiningum jafnréttislaga, en aftur á móti er pað ekki bundið við kynbundna eða kynferðislega áreitni). 
Lagt er bann við mismunun á grundvelli kyns í ákvæðum III. kafla jafnréttislaga, sbr. t.d. 16. gr. sem geymir almenna meginreglu um bann við slíkri mismunun. Einnig er lagt bann við mismunun í kjörum í 18. gr. og í starfi og við ráðningu í 19. gr. Samkvæmt 14. gr. jafnréttislaga hvíla skyldur á atvinnurekendum og yfirmönnum stofnana, félagasamtaka o.fl. um að gera sérstakar ráðstafanir til að koma í veg fyrir að starfsfólk verði fyrir kynbundnu ofbeldi, kynbundinni áreitni eða kynferðislegri áreitni á vinnustað. Atvinnurekandi skal jafnframt gæta pess skv. 2. mgr. 20. gr. laganna að starfsfólk verði ekki beitt órétti í starfi, svo sem með tilliti til starfsöryggis, starfskjara eða mats á árangri, á grundvelli pess að hafa kært eða veitt upplýsingar um kynbundna eða kynferðislega áreitni eða kynjamismunun.

Eins og í tilviki laga nr. 46/1980 og reglugerðar nr. 1009/2015 má líta á forseta Alpingis sem atvinnurekanda í skilningi ákvæða jafnréttislaga nr. 150/2020. Hann ber pví ábyrgð á að gera pær ráðstafanir til verndar starfsfólki Alpingis sem mælt er fyrir um í 1. mgr. 14. gr. og 2. mgr. 20. gr. jafnréttislaga. Alpingismenn teljast aftur á móti ekki til starfsfólks í skilningi jafnréttislaga og falla pví ekki undir gildissvið peirra. Er niðurstaða um petta pví sú sama og í tilviki laga nr. 46/1980 og reglugerðar nr. 1009/2015.

\subsubsection{Samantekt}

एótt alpingismenn falli samkvæmt framansögðu ekki undir gildissvið fyrrnefndra laga nr. 46/1980, reglugerðar nr. 1009/2015 og laga nr. 150/2020 verður að hafa hugfast að í siðareglum fyrir alpingismenn eru sem fyrr segir lagðar á pá skyldur um að skapa í störfum sínum heilbrigt starfsumhverfi innan pings sem utan og að peir skuli ekki sýna öðrum pingmönnum, starfsmönnum pingsins eða gestum kynferðislega eða kynbundna áreitni, leggja pá í einelti eða koma fram við pá á annan vanvirðandi hátt, sbr. d-lið 5. gr. og 8. gr. siðareglnanna, sbr. umfjöllun í 3. kafla. Af peim sökum má segja að í siðareglunum felist sambærilegar kröfur til alpingismanna að pessu leyti og gilda um starfsfólk Alpingis samkvæmt fyrrnefndum lögum og reglugerð. Рá kveða siðareglurnar á um pann farveg sem kvörtunum vegna brota gegn peim verður beint í.

\subsection{Lög nr. 40/2020 um vernd uppljóstrara}

Lög nr. 40/2020 um vernd uppljóstrara eru fyrstu heildarlögin um pað efni. Áður en lög nr. 40/2020 tóku gildi voru komin ákvæði í önnur lög sem varða vernd uppljóstrara á ákveðnum sviðum, sbr. t.d. 13. gr. a laga nr. 70/1996, 18. gr. laga nr. 85/1997 um umboðsmann Alpingis og 60. gr. b laga nr. 161/2002 um fjármálafyrirtæki, en tvenn pau fyrstnefndu gilda pegar stjórnvöld eiga í hlut.

Lög nr. 40/2020 tryggja uppljóstrurum sem falla undir gildissvið peirra aukna réttarvernd og heimildir til uppljóstrunar prátt fyrir reglur um pagnar- eða trúnaðarskyldu. Gildissvið laganna er afmarkað við „starfsmenn sem greina frá upplýsingum eða miðla gögnum í góðri trú um brot á lögum eða aðra ámælisverða háttsemi í starfsemi vinnuveitenda peirra, hvort sem peir starfa hjá hinu opinbera eða á einkamarkaði“. Með góðri trú er átt við að starfsmaður hafi góða ástæðu til að telja gögnin eða upplýsingarnar sem miðlað er réttar, pað sé í págu almennings að miðla peim og að hann eigi ekki annan kost 
til að koma í veg fyrir pau brot eða pá háttsemi sem um ræðir, sbr. 1. mgr. 1. gr. laga nr. 40/2020. Мeð ámælisverðri háttsemi er átt við hátterni sem stefnir almannahagsmunum í hættu, t.d. hátterni sem ógnar heilsu eða öryggi fólks eða umhverfi, án pess að um sé að ræða augljóst brot á lögum eða reglum, sbr. sömu lagagrein. Lögin geyma m.a. reglur um ólíka farvegi uppljóstrunar, p.e. innri og ytri uppljóstrun, sbr. 2. og 3. gr. laganna. Í 3. mgr. 2. gr. laganna er miðað við аð upplýsingum (uppljóstrun) sé almennt, fyrsta kastið, komið á framfæri við „,næsta yfirmann starfsmanns“ og sé móttakanda skylt að stuðla að pví að látið verði af ólögmætri eða ámælisverðri háttsemi eða brugðist á annan hátt við henni. Í 4. gr. laganna er síðan að finna reglur sem ætlað er að tryggja að viðkomandi starfsmenn séu ekki látnir gjalda fyrir uppljóstrun. Uppljóstrarar njóta pannig verndar m.a. gagnvart stjórnsýsluviðurlögum, ípyngjandi úrræðum að starfsmannarétti, óréttlátri meðferð á annan hátt, t.d. skerðingu starfsréttinda, sem og refsi- og skaðabótaábyrgð vegna rofs á pagnarskyldu o.p.h. (sjá Eiríkur Jónsson og Oddur Porri Viðarsson 2019, 580-582).

раð eru fyrst og fremst „starfsmenn“ sem njóta góðs af reglum um uppljóstraravernd skv. lögum nr. 40/2020, hvort sem peir hafa látið af störfum eða ekki pegar til uppljóstrunar kemur. Hugtakið starfsmaður er skilgreint í 2. mgr. 1. gr. laga nr. 40/2020 sem sá „sem hefur aðgang að upplýsingum eða gögnum um starfsemi vinnuveitanda vegna hlutverks síns, p.m.t. ráðinn, settur, skipaður, sjálfstæett starfandi verktaki, stjórnarmaður, starfsnemi, tímabundinn starfsmaður og sjálfboðaliði“. Tilvitnuð skilgreining á starfsmanni á rætur að rekja til tillögu meiri hluta allsherjar- og menntamálanefndar (150. löggj.p. 2019-2020, pskj. 1235 - 362. mál), en hugtakið var prengra í upphaflegu frumvarpi til laganna.

Í lögum nr. 40/2020 er ekki að finna ákvæði sem gefa tilefni til annarrar ályktunar en að gildissvið laganna nái almennt séð til Alpingis sem vinnustaðar á vegum hins opinbera. Óljósara er á hinn bóginn hvort alpingismenn falli undir hina sérstöku skilgreiningu 2. mgr. 1. gr. laganna á hugtakinu starfsmaður. Pótt sú skilgreining sé víðtækari en í vinnurétti almennt, eins og framangreind umfjöllun ber með sér, mælir sérstaða alpingismanna sem lýðræðislegra kjörinna fulltrúa almennt gegn pví að peir verði virtir sem starfsmenn í lagalegum skilningi, sbr. fyrri umfjöllun m.a. um lög nr. 46/1980, reglugerð nr. 1009/2015 og lög nr. 150/2020. Samkvæmt pví virðist hæpið að litið yrði á alpingismenn sem starfsmenn í skilningi laga nr. 40/2020.

Lög nr. 40/2020 gera ráð fyrir pví að í fyrirtækjum eða á öðrum vinnustöðum, par sem 50 starfsmenn eða fleiri starfa að jafnaði á ársgrundvelli, skuli atvinnurekandi í samráði við starfsmenn setja reglur um verklag við uppljóstrun um lögbrot eða aðra ámælisverða háttsemi í starfsemi vinnuveitandans, m.a. um móttöku, meðhöndlun og afgreiðslu slíkra tilkynninga, en pessar reglur skulu vera aðgengilegar starfsmönnum, sbr. 1. mgr. 5. gr. laganna. Í 2. mgr. 5. gr. er kveðið á um að ráðherra sem fer með starfsmannamál ríkisins setji reglur skv. 1. mgr. fyrir „opinberar stofnanir og lögaðila í opinberri eigu“. Skal Vinnueftirlit ríkisins jafnframt birta fyrirmynd að reglum fyrir aðra vinnustaði á vef sínum.

Pótt ekki sé minnst á Alpingi og stofnanir sem heyra undir pað í 2. mgr. 5. gr. laga nr. 
40/2020 virðist ekkert mæla gegn pví að líta svo á að pingið sjálft og stofnanir pess falli undir almennu regluna í 1. mgr. 5. gr., sem tekur til fyrirtækja og ,,annarra vinnustaða“ par sem 50 starfsmenn eða fleiri starfa að jafnaði á ársgrundvelli, og leggur í hendur atvinnurekanda að setja reglur um verklag við uppljóstrun í samráði við starfsmenn, eins og fyrr segir. Ætla verður að forseti Alpingis myndi skoðast sem atvinnurekandi í pessu sambandi, á sama hátt og í skilningi laga nr. 46/1980, og að hann beri pví ábyrgð á að setja vinnustaðnum reglur á grundvelli 5. gr. laga nr. 40/2020. Verður enda ekki annað ráðið af ákvæðum laga nr. 40/2020 en að gildissvið peirra geti almennt séð náð til Alpingis sem vinnustaðar á vegum hins opinbera, eins og fyrr segir.

\section{5. Álitaefni varđandi refsiábyrgð}

Í pessum kafla verður fjallað um hvort og pá með hvaða hætti alpingismenn geti bakað sér refsiábyrgð á grundvelli almennra hegningarlaga nr. 19/1940 vegna háttsemi sem lagt er bann við í d-lið 1. mgr. 5. gr. og 8. gr. siðareglna fyrir alpingismenn, p.e. kynferðislegrar eða kynbundinnar áreitni, eineltis eða annarrar vanvirðandi framkomu í garð annarra alpingismanna, starfsmanna Alpingis eða gesta pess, sbr. umfjöllun í 3. kafla hér að framan. Verður einnig leitast við að svara pví hvort alpingismenn lúti öðrum reglum um refsiábyrgð en gilda um almenna borgara vegna háttsemi sem hér um ræðir, m.a. með tilliti til friðhelgi sem alpingismenn njóta skv. 49. gr. stjórnarskrárinnar.

\subsection{Almenn hegningarlög}

Allflest ákvæði almennra hegningarlaga nr. 19/1940 hafa almennt gildissvið að pví leyti að verknaðarlýsingar peirra eru ekki bundnar við ákveðna hópa gerenda. Af pví leiðir að alpingismenn geta gerst sekir um brot gegn peim ákvæðum hegningarlaga sem hér hafa pýðingu, ef viðkomandi háttsemi fellur að hlutrænum og hugrænum efnispáttum viðkomandi refsiákvæða (sjá nánar um grunnskilyrði refsiábyrgðar um refsinæmi, ólögmæti og saknæmi í Jónatan Pórmundsson 1999, 37-42). Vegna háttsemi sem greinir í d-lið 1. mgr. 5. gr. og 8. gr. siðareglna fyrir alpingismenn gætu t.d. eftirfarandi ákvæði hegningarlaga komið til skoðunar: 199. gr. (kynferðisleg áreitni), 209. gr. (blygðunarsemisbrot), 217. gr. (líkamsárás), 228. gr. (brot gegn friðhelgi einkalífs), 233. gr. (hótun um að fremja refsiverðan verknað) og 234. gr. (ærumeiðingar), svo að dæmi séu tekin. Hvað varðar kynferðislega áreitni sérstaklega, sbr. 199. gr. hegningarlaga, getur bæði verið um að ræða líkamlega snertingu eða táknræna hegðun eða orðbragð sem er mjög meiðandi, ítrekað eða til pess fallið að valda ótta (um nánari umfjöllun um 199. gr. hegningarlaga, sjá Ragnheiður Bragadóttir 2018, 353-355, 357-374).

Hér ber að nefna að í hegningarlögum er ásetningur yfirleitt áskilinn sem huglægt skilyrði refsiábyrgðar, sbr. 18. gr. hegningarlaga. Gáleysi nægir pví ekki nema sérstök heimild sé í viðkomandi refsiákvæði til að refsa einnig fyrir brot sem framin eru af gáleysi (sjá nánar Jónatan Dórmundsson 2002, 22-23). Ekkert peirra refsiákvæða sem nefnd voru í dæmaskyni hér að framan geymir slíka heimild og gildir pví meginregla 18. gr. hegningarlaga um pau, p.e. að gerð er krafa um að brot sé framið af ásetningi.

Eins og fyrr segir eru verknaðarlýsingar fyrrnefndra refsiákvæða hegningarlaga ekki 
takmarkaðar við ákveðna hópa gerenda og leikur pví ekki vafi á pví að alpingismenn geta fallið undir pau eins og á raunar við um allflest önnur ákvæði laganna. Sem dæmi um hið gagnstæða má nefna XIV. kafla laganna sem fjallar um brot opinberra starfsmanna (Jónatan Pórmundsson 1999, 138). Hugtakið opinber starfsmaður er skilgreint í 141. gr. a en ákvæðinu var bætt inn í lögin með lögum nr. 54/2003 til að taka af vafa um merkingu hugtaksins (sjá umfjöllun um eldra réttarástand í Róbert R. Spanó 1999, 522). Ljóst er að alpingismenn falla ekki undir hugtakið opinber starfsmaður, en til marks um pað má benda á að 128. gr. hegningarlaga, sem fjallar um mútubrot opinberra starfsmanna, var breytt pannig með lögum nr. 5/2013 að bætt var við greinina beinni tilvísun til alpingismanna (og gerðarmanna), til að taka af skarið um að peir geti framið mútubrot á sama hátt og opinberir starfsmenn. Sú breyting var gerð vegna fullgildingar á viðbótarbókun við samning Evrópuráðsins á sviði refsiréttar um spillingu frá 15. maí 2003 (141. löggj.p. 2012-2013, pskj. 130 - 130. mál, 2). Öðru máli gegnir pó ef alpingismenn gegna aukastörfum fyrir hið opinbera, t.d. sem ráðherrar eða starfsmenn stjórnsýslunefnda. Sem dæmi um pá aðstöðu má vísa til dóms Hastaréttar 6. februar 2003 i máli nr. 393/2002. Málið varðaði ákæru fyrir fjárdrátt, mútupægni og fleiri brot sem ákærði hafði framið sem formaður byggingarnefndar Djóðleikhússins. Ákærði hafði jafnframt gegnt störfum sem alpingismaður pegar brotin voru framin en hafði sagt af sér pingmennsku áður en hann var ákærður fyrir brotin. Niðurstaða málsins var sú að ákærði var sakfelldur og dæmdur til tveggja ára óskilorðsbundinnar fangelsisvistar. Hafði pað áhrif til refsipyngingar að ákærði framdi brotin í skjóli stöðu sinnar sem opinber starfsmaður, p.e. sem formaður byggingarnefndar Pjóðleikhússins, sbr. 138. gr. hegningarlaga.

Pótt pessi kafli lúti samkvæmt heiti sínu að almennum hegningarlögum er rétt að taka fram samhengisins vegna að refsiheimildir geta einnig birst í öðrum sérhæfðari lögum. Til að mynda er í 99. gr. laga nr. 46/1980 аð finna almennt orðaða refsiheimild sem leggur sektarrefsingu við brotum gegn öðrum ákvæðum laganna og reglugerðum settum samkvæmt peim, nema pyngri refsing liggi við að öðrum lögum (t.d. hegningarlögum). Par sem alpingismenn teljast ekki til starfsmanna í skilningi laga nr. 46/1980 og reglugerðar nr. 1009/2015 hefur umrædd refsiheimild 99. gr. laganna takmarkaða pýðingu í pví samhengi sem hér um ræoir.

Samkvæmt pví sem hér hefur verið rakið geta alpingismenn bakað sér refsiábyrgð vegna háttsemi sem fer gegn d-lið 1. mgr. 5. gr. og 8. gr. siðareglna fyrir alpingismenn, ef sú háttsemi uppfyllir hlutræn og hugræn skilyrði refsiákvæða í hegningarlögum. Refsiábyrgð verður að jafnaði ekki slegið fastri nema í sakamáli fyrir dómi að undangenginni rannsókn lögreglu og útgáfu ákæru. Í peim efnum getur pó reynt á friðhelgi alpingismanna skv. 1. mgr. 49. gr. stjórnarskrárinnar sem nú verður vikið að.

\subsection{Friðhelgi skv. 1. mgr. 49. gr. stjórnarskrárinnar}

Eins og framan er rakið fer um refsiábyrgð alpingismanna að mestu eftir almennum reglum. Hins vegar njóta peir vissra sérréttinda skv. 1. mgr. 49. gr. stjórnarskrárinnar eins og áður hefur verið vikið að og sem vert er að fjalla nánar um. Í ákvæðinu er kveðið á um að á meðan Alpingi er að störfum megi ekki setja alpingismann í gæsluvarðhald eða 
höfða mál á móti honum án sampykkis pingsins nema hann sé staðinn að glæp. Friðhelgi pessi takmarkast við pær aðgerðir sem nefndar eru í ákvæðinu, p.e. annars vegar gæsluvarðhald skv. XIV. kafla laga nr. 88/2008 um meðferð sakamála og hins vegar höfðun sakamáls með útgáfu ákæru, sbr. 152. gr. sömu laga. Hvað gæsluvarðhald varðar er friðhelgin enn fremur lögfest í 96. gr. umræddra laga (Björg Thorarensen 2015, 306-311; Ólafur Jóhannesson 1978, 229-232; Gunnar G. Schram 1999, 233-235).

Eins og leitt verður af orðalagi 1. mgr. 49. gr. stjórnarskrárinnar njóta alpingismenn umræddrar friðhelgi einvörðungu meðan Alpingi er að störfum. Friðhelgin fellur pví almennt niður við pingfrestun, sbr. 1. mgr. 23. gr. stjórnarskrárinnar. Talið er að pað eigi pó aðeins við um pingfrestun með sampykki Alpingis sjálfs, p.e. lengur en tvær vikur, enda væri stjórninni annars í lófa lagið að fara í kringum friðhelgina með pví að fresta fundum Alpingis og höfða mál gegn alpingismanni meðan frestunin varir (Ólafur Jóhannesson 1978, 230; Björg Thorarensen 2015, 308). Pá gildir friðhelgin ekki ef Alpingi, p.e. meiri hluti alpingismanna, sampykkir að fella hana niður í einstöku tilviki, eða ef alpingismaður er „staðinn að glæp“. Мeð glæp er vísað til alvarlegra ásetningsbrota og er pað í samræmi við viðtekinn skilning á pví hugtaki í refsirétti (sjá Björg Thorarensen 2015, 309; Bjarni Benediktsson 1940, 14).

Friðhelgi skv. 1. mgr. 49. gr. stjórnarskrárinnar gildir um alpingismenn, hvort sem peir gegna jafnframt ráðherraembætti eða ekki. Íslenskir fræðimenn hafa á hinn bóginn verið ósammála um hvort friðhelgin nái til utanpingsráðherra. Ólíkt eldri fræðiskrifum telur Björg Thorarensen hæpið að 1. mgr. 49. gr. stjórnarskrárinnar verði beitt með lögjöfnun um utanpingsráðherra í ljósi peirra raka sem stjórnarskrárákvæðið hvílir á, sem er sama niðurstaða og í dönskum rétti um samsvarandi ákvæði dönsku stjórnarskrárinnar (sjá Björg Thorarensen 2015, 307). Röksemdir fyrir friðhelginni voru upprunalega pær að handhafar framkvæmdarvalds sem einnig fóru með ákæruvaldið gætu reynt að hindra eða trufla pingstörf alpingismanna með höfðun sakamáls, e.t.v. að ástæðulausu (Björg Thorarensen 2015, 309). Hér verður tekið undir sjónarmið Bjargar um að hæpið sé að utanpingsráðherra geti notið góðs af friðhelgi skv. 1. mgr. 49. gr. stjórnarskrárinnar á grundvelli lögjöfnunar frá ákvæðinu, enda verður hvorki séð að staða utanpingsráðherra sé efnislega sambærileg peim tilvikum sem falla undir sérstaka friðhelgisreglu 1. mgr. 49. gr. stjórnarskrárinnar né að sömu rök eigi við um tilvikin. Dví geta almenn skilyrði lögjöfnunar ekki talist uppfyllt.

pegar öllu er á botninn hvolft verður raunhæf pýðing friðhelgi skv. 1. mgr. 49. gr. stjórnarskrárinnar að teljast takmörkuð enda kemur stjórnarskrárákvæðið ekki í veg fyrir að hafin sé sakamálarannsókn vegna gruns um refsivert brot alpingismanns jafnvel pótt pingið sé að störfum. Ákæra yrði pó ekki gefin út á hendur alpingismanni né yrði hann úrskurðaður í gæsluvarðhald meðan pingið væri að störfum nema með sampykki pingsins eins og 1. mgr. 49. gr. kveður á um. Rétt er að árétta að hafi alpingismaður sagt af sér pingmennsku áður en ákæra er gefin út koma pessi ákvæði eðli málsins samkvæmt ekki til skoðunar, sbr. til hliðsjónar dóm Hastaréttar 6. febrúar 2003 i máli nr. 393/2002 sem áður var fjallað um. 


\subsection{Afleiðingar dóms um óskilorðsbundna fangelsisrefsingu}

Í tengslum við refsiábyrgð alpingismanna er rétt að víkja stuttlega að áhrifum pess ef alpingismaður er dæmdur til óskilorðsbundinnar fangelsisrefsingar. Áður hefur verið vikið að pví að einstaklingur er ekki kjörgengur til Alpingis nema hann hafi óflekkað mannorð, sbr. 1. mgr. 34. gr. stjórnarskrárinnar. Mannorð telst ekki óflekkað meðan viðkomandi afplánar óskilorðsbundna fangelsisrefsingu sem hann hefur hlotið með dómi fyrir refsivert brot, sbr. 5. gr. laga nr. 24/2000 um kosningar til Alpingis, eins og ákvæðinu var breytt með 2. gr. laga nr. 141/2018 (rétt er að geta pess að ákvæðið verður 3. mgr. 6. gr. í kosningalögum nr. 112/2021 sem taka gildi 1. janúar 2022). Árétta ber að „flekkun mannorðs“ 1 skilningi 5. gr. laga nr. 24/2000 varir einvörðungu meðan á afplánun óskilorðsbundins refsidóms stendur. Getur alpingismaður samkvæmt pessu glatað kjörgengi vegna dóms um óskilorðsbundna fangelsisrefsingu, með peim afleiðingum að hann missi „rétt pann, er pingkosningin hafði veitt honum“, sbr. 50. gr. stjórnarskrárinnar. Samkvæmt 46. gr. stjórnarskrárinnar er pað Alpingi sjálft sem sker úr pví hvort alpingismaður hafi misst kjörgengi sitt. Ætti pó ekki að vera vafa undirorpið hvenær alpingismaður telst ekki lengur uppfylla skilyrði kjörgengis um óflekkað mannorð enda gefur pað ekkert svigrúm til mats.

\section{6. Álitaefni varðandi skaðabótaábyrgð}

Í umfjöllun pessa kafla um skaðabótaskyldu er, eins og 1́ 5. kafla, höfð í huga háttsemi sem lagt er bann við í d-lið 1. mgr. 5. gr. og 8. gr. siðareglna fyrir alpingismenn, p.e. kynferðisleg og kynbundin áreitni, einelti og önnur vanvirðandi framkoma gagnvart öðrum pingmönnum, starfsfólki Alpingis eða gestum pess, sbr. umfjöllun í 3. kafla hér að framan. Verður einnig vikið að pví hvort friðhelgi alpingismanna skv. 49. gr. stjórnarskrárinnar geti haft hér áhrif.

\subsection{Almennt um skaðabótaábyrgð}

Óháð pví hvort háttsemi sé refsiverð eða ekki parf að skoða sjálfstætt hvort hún uppfylli skilyrði skaðabótaábyrgðar. Til að hafa megi uppi kröfu um fjártjónsbætur á grundvelli almennu sakarreglunnar parf viðkomandi háttsemi að vera saknæm og ólögmæt auk pess að hafa valdið fjárhagslegu tjóni (Eiríkur Jónsson \& Viðar Már Matthíasson 2015, 93-94). Öðru máli gegnir um miskabætur skv. 26. gr. skaðabótalaga nr. 50/1993 að pví leyti að pær verða dæmdar óháð pví hvort fjárhagslegt tjón hafi hlotist af háttseminni, enda er miskabótum ætlað að bæta ófjárhagslegt tjón (Eiríkur Jónsson og Viðar Már Matthíasson 2015, 561-564; um möguleikann á að sækja jafnframt bætur fyrir varanlegan miska skv. I. kafla skaðabótalaga vegna kynferðisbrota, sjá Eiríkur Jónsson 2012, 101 107; Ása Ólafsdóttir 2006, 13-14).

Dótt skilyrði refsiábyrgðar og skaðabótaábyrgðar séu ekki alltaf pau sömu er engu að síður nokkur skörun milli peirra pegar um ræðir ofbeldis- og kynferðisbrot og pá sérstaklega skilyrða miskabóta skv. 26. gr. skaðabótalaga enda eru pær ekki háðar pví að háttsemi hafi valdið fjárhagslegu tjóni sem fyrr segir (Ása Ólafsdóttir 2006, 12-14, 
36). Skilyrði miskabóta geta einnig verið fyrir hendi jafnvel pótt viðkomandi háttsemi sé ekki refsiverð að lögum. Рað getur t.d. átt við í tilviki hegðunar á borð við einelti og áreitni pegar ekki er jafnframt um að ræða háttsemi sem varðar við refsiákvæði, sbr. einnig umfjöllun í kafla 5.1 hér að framan. Að sama skapi er heldur ekkert sem útilokar að dæmdar séu miskabætur fyrir háttsemi í einkamáli pótt handhafi ákæruvalds láti hjá líða að höfða sakamál vegna sömu háttsemi, sbr. til hliðsjónar Hrd. 22. september 2005 i máli nr. 49/2005.

Með hliðsjón af framansögðu er ekki vafa undirorpið að háttsemi alpingismanna sem fer gegn d-lið 1. mgr. 5. gr. og 8. gr. siðareglna fyrir alpingismenn getur orðið grundvöllur skaðabótaskyldu, t.d. miskabóta skv. 1. mgr. 26. gr. skaðabótalaga. Рað rennir alla jafna stoðum undir skaðabótaskyldu að um sé að ræða háttsemi sem fer gegn skráðum eða óskráðum hátternisreglum (Eiríkur Jónsson \& Viðar Már Matthíasson 2015, 126167). Pví verður að ætla að siðareglurnar styrki grundvöll skaðabótaskyldu vegna háttsemi sem pær leggja bann við, sbr. einnig umfjöllun í 3. kafla hér að framan.

Tekið skal fram að önnur sjónarmið eiga við um ábyrgð alpingismanna vegna pátttöku í löggjafarstarfinu, en í peim efnum eru peir einungis bundnir við sannfæringu sína og njóta pví ríks frelsis um hvernig peir rækja pingstörfin, sbr. 48. gr. stjórnarskrárinnar, sbr. einnig umfjöllun í 2. kafla. Detta síðastnefnda atriði breytir pví pó ekki að alpingismönnum ber við störf sín að hlíta ákvæðum pingskapalaga og siðareglna sem og að lúta valdi forseta Alpingis um góða reglu í pingstörfum (Björg Thorarensen 2015, 306).

\subsection{Vernd tjáningar skv. 2. mgr. 49. gr. stjórnarskrárinnar}

Í sambandi við skaðabótaábyrgð má enn fremur vekja athygli á pví að alpingismenn njóta vissrar verndar gagnvart málshöfðun í einkamáli skv. 2. mgr. 49. gr. stjórnarskrárinnar ef dómkröfur, t.d. um skaðabætur, eiga rætur að rekja til tjáningar alpingismanns á vettvangi Alpingis og í tengslum við störf hans. Nefnt stjórnarskrárákvæði mælir fyrir um að enginn alpingismaður verði „krafinn reikningsskapar utan pings fyrir pað sem hann hefur sagt í pinginu nema Alpingi leyfi“. Ólíkt friðhelgi skv. 1. mgr. 49. gr. stjórnarskrárinnar (sbr. kafla 5.2) er vernd tjáningar alpingismanns skv. 2. mgr. 49. gr. stjórnarskrárinnar ótímabundin og er hún ekki háð pví að pingið sé að störfum.

Talið er að munnleg jafnt sem skrifleg tjáning rúmist innan 2. mgr. 49. gr. stjórnarskrárinnar. Ákvæðið girðir t.d. fyrir að alpingismaður verði sóttur í einkamáli til greiðslu bóta vegna ummæla sem hann hefur viðhaft í pinginu. Hið sama á við um höfðun einkarefsimáls af slíku tilefni (Björg Thorarensen 2015, 311-316; Ólafur Jóhannesson 1978, 232-237; Gunnar G. Schram 1999, 235-239). Pví hefur verið haldið fram að par sem regla 2. mgr. 49. gr. stjórnarskrárinnar sé sett í págu fulltrúasamkomunnar sem heildar en ekki einstakra alpingismanna, geti alpingismaður ekki fallist á málshöfoun á hendur sér án sampykkis pingsins (sjá Dórhall Vilhjálmsson 2019, 56-57. Pórhallur vísar til umfjöllunar Gunnars Thoroddsen 1967, 261, um að ekki skipti máli pó að pingmaður sampykki að svara til saka í dómsmáli eða að hann óski eftir pví að mál fari fyrir dóm). Hafa ber pó í huga að vernd skv. 2. mgr. 49. gr. stjórnarskrárinnar er háð pví skilyrði að tjáning alpingismanns eigi sér stað „í pinginu“, t.d. í ræðustól Alpingis. Ummæli sem alpingis- 
maður léti falla á öðrum vettvangi, t.d. í viðtali í fjölmiðlum, myndu pví að jafnaði falla utan peirrar verndar. Samkvæmt pví gæti alpingismaður afsalað sér vernd 2. mgr. 49. gr. stjórnarskrárinnar með pví að endurtaka ummæli á öðrum vettvangi en Alpingi (Björg Thorarensen 2015, 313-314).

Eins og fram hefur komið er friðhelgi gagnvart málsókn í einkamáli skv. 2. mgr. 49. gr. stjórnarskrárinnar bundin við tjáningu alpingismanns sem parf auk pess að standa í nægum tengslum við störf hans. Af peim sökum verður almennt að telja pað hæpið að 2. mgr. 49. gr. stjórnarskrárinnar myndi hindra höfðun einkamáls á hendur alpingismanni vegna orðbragðs eða framkomu sem bönnuð er í d-lið 1. mgr. 5. gr. og 8. gr. siðareglna fyrir alpingismenn.

\section{Niðurstöður}

Í pessari grein hefur sjónum verið beint að pví hvaða reglur gilda pegar alpingismenn sýna af sér óæskilega hegðun eins og einelti, kynferðislega og kynbundna áreitni og ofbeldi á vettvangi Alpingis. Í ljósi pess að siðareglur fyrir alpingismenn leggja bann við slíkri háttsemi af hendi alpingismanna við störf peirra innan sem utan pings auk pess að kveða á um málsmeðferð vegna slíkra brota má segja að sambærilegar reglur gildi í raun um alpingismenn og pær sem taka til starfsfólks Alpingis í lögum nr. 46/1980, reglugerð nr. 1009/2015 og lögum nr. 150/2020. Má pví segja að pað leiði af siðareglunum að sambærilegar kröfur eru gerðar til alpingismanna og starfsfólks Alpingis hvað slíka óæskilega hegðun varðar, pó svo að alpingismenn teljist vegna sérstöðu sinnar í stjórnskipuninni ekki til starfsmanna eða starfsfólks í skilningi fyrrgreindra laga og reglugerðar. Pá geta alpingismenn bakað sér refsiábyrgð samkvæmt hegningarlögum sem og skaðabótaábyrgð vegna háttsemi sem lagt er bann við í siðareglunum, að uppfylltum skilyrðum slíkrar ábyrgðar. Pótt alpingismenn njóti vissrar friðhelgi samkvæmt stjórnarskránni er umfang hennar takmarkað auk pess sem Alpingi getur ávallt ákveðið að aflétta henni.

Fram kemur í greinargerð með tillögu til pingsályktunar nr. 18/148 að ráðgert sé að setja sérstaka viðbrags- og aðgerðaáætlun vegna mála sem falla undir siðareglur fyrir alpingismenn, en slík áætlun er fyrir hendi er varðar starfsfólk Alpingis. Við mótun á slíkri áætlun fyrir alpingismenn af hálfu Alpingis verður að telja að vel kæmi til greina að hafa hliðsjón af reglum og verkferlum fyrrnefndra laga og reglugerðar á sviði vinnuverndar sem gilda eins og áður segir um starfsfólk Alpingis, að teknu tilliti til sérstöðu alpingismanna í stjórnskipuninni.

\section{Heimildir}

Alpingistíðindi.

Ármann Snævarr (1989). Almenn lögfrcoti. Reykjavík: Bókaútgáfa Orators.

Ása Ólafsdóttir (2006). „Kynferðisbrot og ákvörðun miskabóta“, í Eyvindur G. Gunnarsson (ritstj.), Rannsóknir i félagsvísindum VII : lagadeild (bls. 11-59). Reykjavík: Félagsvísindastofnun Háskóla Íslands. Áætlun um aðgerðir gegn einelti, kynferðislegri og kynbundinni áreitni og ofbeldi, 3. útgáfa, júní 2021. Sótt af https://www.althingi.is/um-althingi/skrifstofa-althingis/starfsmannamal/aaetlun-um-adgerdir-gegn-einelti-kynferdislegri-og-kynbundinni-areitni-og-ofbeldi/

Bjarni Benediktsson (1940). Ágrip af islenskeri stjórnlagafraði II. Reykjavík: Handrit. 
Björg Thorarensen (2015). Stjórnskipunarréttur. Undirstöjur og handhafar ríkisvalds. Reykjavík: Codex.

Erikson, J. og Josefsson, C. (2020). ,The Parliament as a Gendered Workplace: How to Research Legislators' (UN)Equal Opportunities to Represent", Parliamentary Affairs 0, 1-19.

Eiríkur Jónsson (2012). „Skaðabætur vegna kynferðisbrota - er réttur brotapola ekki að fullu sóttur?“, Timarit lögradinga 62(1), 79-112.

Eiríkur Jónsson og Oddur Porri Viðarsson (2019). „Uppljóstraravernd opinberra starfsmanna“, í Hafsteinn Dan Kristjánsson (risti.), Stjórnsýslulögin 25 ára (bls. 569-602). Reykjavík: Forsætisráðuneytið.

Eiríkur Jónsson og Viðar Már Matthíasson (2015). Bótaréttur I. Reykjavík: Bókaútgáfan Codex.

Gunnar G. Schram (1999). Stjórnskipunarréttur (2. útg.). Reykjavík: Háskólaútgáfan.

Gunnar Thoroddsen (1967). Fjölmali. Reykjavík: Menningarsjóður.

Jafnréttisáætlun skrifstofu Alpingis, 11. maí 2021. Sótt af https://www.althingi.is/um-althingi/skrifstofa-althingis/starfsmannamal/jafnrettisaaetlun/

Jónatan Dórmundsson (1999). Afbrot og refsiábyrgð I. Reykjavík: Háskólaútgáfan.

Jónatan Bórmundsson (2002). Afbrot og refsiábyrgo II. Reykjavík: Háskólaútgáfan.

Ólafur Jóhannesson (1978). Stjórnskipun Íslands (2. útg). Reykjavík: Iðunn.

Ragnheiður Bragadóttir (2018): Nauðgun og önnur brot gegn kynfrelsi fólks. Reykjavík: Bókaútgáfan Codex.

Reglur um meðferð erinda og málsmeðferð samkvæmt siðareglum fyrir alpingismenn, 29. ágúst 2016: Sótt af https://www.althingi.is/um-althingi/upplysingar-um-althingi/reglur-settar-af-forsaetisnefnd-/adrar-reglur-og-samthykktir/brot-a-sidareglum/

Róbert R. Spanó (1999). „Lagareglur um refsiábyrgð opinberra starfsmanna“, Úlfljótur 52(4), 511-529.

Siðareglur fyrir alpingismenn (samkvæmt ályktunum Alpingis 23/145 og 18/148): Sótt af https://www. althingi.is/thingmenn/hagsmunaskraning/sidareglur/

Sigurður Líndal (2007). Um lög og lögrađđi. Grundvöllur laga - Réttarbeimildir (2. útg). Reykjavík: Hið íslenzka bókmenntafélag.

Stefanía Óskarsdóttir (2011). „Dróun íslenska stjórnmálakerfisins“, í Ragnhildur Helgadóttir, Helgi Skúli Kjartansson og Porsteinn Magnússon (ritstj.), Dingraèi á Íslandi. Samtí og saga (bls. 229-257). Reykjavík: Forlagið.

Porsteinn Magnússon (2011). „Sampætting meginvaldpátta ríkisins“, í Ragnhildur Helgadóttir, Helgi Skúli Kjartansson og Porsteinn Magnússon (ritstj.), Dingradi á Íslandi. Samtíd og saga (bls. 323-360). Reykjavík: Forlagið.

Dórhallur Vilhjálmsson (2019). „Um tjáningarfrelsi pingmanna og sjálfræði Alpingis“, Úlfjótur 72(1), 49-94. 